\title{
Analyzing Quality of University Life Perceptions of the Students of School of Physical Education and Sports
}

\author{
Gökhan Arıkan (Corresponding author) \\ School of Physical Education and Sports \\ Harran University, Şanlıurfa, Turkey \\ Tel: 90-532-636-3661Ｅ-mail: arikangokhan@hotmail.com
}

Received: August 1, 2020 Accepted: August 31, 2020 Published: September 7, 2020

doi:10.5296/jei.v6i2.17470ＵRL: https://doi.org/10.5296/jei.v6i2.17470

\begin{abstract}
In this sense, the improvements to be made for all the dimensions in the scale highlight the importance of this study to determine the problems students will encounter during their school life and to reflect these experiences to students or athletes after graduation. Quality of school life can be considered as an indicator of students' communication, love and respect towards other individuals at the school, and their satisfaction with all kinds of physical and social facilities of the school. In the field of quality of school life education, research has examined the issue of quality of university life, which is the highest level of education and training. The educational structure and administrative differences of universities made it compulsory to examine the quality of university life separately. Quality of university life includes the level of satisfaction with the university and the constructive experiences of students in the learning process. The study aimed to examine the differences of Harran University School of Physical Education and Sports students' scores obtained from the dimensions of the "Quality of University Life Scale" according to gender, athlete identity, year of study, age, and residence variables. The research consisted of 311 participants in total, 135 females and 176 males. Independent sample t-test and one-way analysis of variance (ANOVA) were performed to determine whether the quality of university life varied according to the variables of students. A statistically significant difference was found in social opportunities dimension in favor of males, in participation in decisions dimension in favor of females, and in student-student communication dimension in favor of males, and in identity, social opportunities and future dimensions according to year of study $(\mathrm{p}<.05)$. In the study, no difference was found among students regarding the gender variable and quality of life. As a result, it is thought that increasing the quality of life in universities will increase the academic success of the student group, and the faculties will become institutions that train more qualified, happier and equipped teachers.
\end{abstract}


Keywords: University, Quality of life, Physical education, Sports, Education, School

\section{Introduction}

Quality of school life can be considered as an indicator of students' communication, love and respect towards other individuals at the school, and their satisfaction with all kinds of physical and social facilities of the school.

Universities differ in terms of education and training opportunities, academic and administrative staff numbers and qualifications, social opportunities, research and development, communication, accommodation and transportation opportunities. This situation may lead to differences in students' perceptions of university life quality in the university learning process. At the same time, considering another dimension, it is thought that their expectations of social-cultural and sports activities may also differ. This study was carried out to examine the quality of university life of the students of the School of Physical Education and Sports.

The multi-component concept of quality of life is a whole. Education, which is one of the most important factors in this concept, constitutes one of the most important dimensions of the overall quality of life. According to (Doğanay \& Sar1, 2006), as the school being one of the indicators of the quality of life, it expresses the level of satisfaction of the children for many years while growing up with the demands and expectations of the society since childhood. As with the quality of life, it is not successful enough to make a statement that contains only one discipline due to the multifaceted nature of the concept of quality of school life. The reason for this is that both objective and subjective components are among the dimensions of the quality of life (Karaduman, 2006). However, the concept of quality is directly proportional to the perceptions of the individual in terms of subjectivity and relativity, and this reflects the socio-cultural characteristics of the person (Ersoy, 2005). The fact that the quality of school life including these features has more than one dimension has caused not to make clear expressions in explaining this concept. Many research studies about the quality are available in the world and Turkey with the title life quality in the field of health (Schuster, 2005; Baştuğ et al., 2018; Ertem et al., 2009; Kılınç, 2016; Al-Huwailah, 2017; Çilhoroz, 2018; Trajkovska-Anchevska \& Trajkov, 2019). Also, in the field of edlucation in Turkey, studies for students regarding quality of life have started to be conducted. Many of these studies are in the field of examining the perception of quality of life of students in the university, as well as their quality of school life (Eriş, 2016; Keleş \& Taşkıran, 2017; Özdemir, 2018; Doğanay \& Sarı, 2006).

In the field of quality of school life education, research has examined the issue of quality of university life, which is the highest level of education and training. The educational structure and administrative differences of universities made it compulsory to examine the quality of university life separately. Quality of university life includes the level of satisfaction with the university and the constructive experiences of students in the learning process (Eriş, 2016).

Quality of life is considered as an important element of education in the university, and it is important in terms of students reaching the desired level (Mok \& Flynn, 2002). Quality of 
school life means that education provides students with the desired achievements academically, socially, and culturally as well as in terms of sports and health at an optimum level (Doğanay \& Sar1, 2006). Akyüz et al. (2017) determined that the quality of life and happiness concepts of the students studying in the School of Physical Education and Sports were positively related to each other and as the quality of life of the students increased, the level of their happiness increased.

Considering that the student groups spend most of their time at school, improving the quality of the schools will make great contributions to students' feelings and thoughts towards the school and all aspects related to school and help them reach the desired level in terms of academic achievement and social and psychological states. The high quality of school life in the development of students' academic and sportive achievements will contribute significantly to the maximum level of acquisition of the targeted achievements.

Another factor that affects the academic success and positive behavior of university students is that it is thought that there will be studies in this direction that will contribute to their school life. As in all higher education institutions, a student's successfiul graduation from these departments is not only connected with the success of the courses defined in the official program, but also with the fact that the student is well designed and able to meet his/her needs (Özdemir, 2012).

\section{Method}

\subsection{Data Collection Tools}

In this study, the reliability analysis of "Quality of University Life Scale" developed by Doğanay and Sarı was performed with the scores obtained from the participants, and the reliability coefficient (Cronbach's Alpha) was calculated as 0.82 for the entire scale. The scale consists of 33 items and seven sub-dimensions. The sub-dimensions are; Instructor-Student Communication (18-24-25-30-31-33); Identity (6-8-12-17-23); Social Opportunities (2-7-14-20-29); Participation in Decisions (4-11-16-22-27-32); Student-Student Communication (5-10-19-26); Future (1-13-28); and Classroom Environment (3-9-15-21), respectively. The scale is a five-point Likert-type scale rated as "I totally disagree" (1 point), "I disagree" (2 points), "I am neutral" (3 points), "I agree" (4 points), and "I totally agree" (5 points).

\subsection{Data Analysis}

SPSS 22.0 package program was used for the analysis of the data obtained. Parametric tests were used for each variable (gender, athlete license, year of study, age, residence) after the normality analyses were performed before each analysis since the data were fit for the normality assumption. Independent sample t-test was used to determine whether quality of university life differentiated according to gender and athlete license variables, and one-way analysis of variance (ANOVA) was used to determine whether it differentiated according to year of study, age and residence variables. 


\section{Macrothink}

\subsection{Population and Sampling}

When Table 1 is examined, it is seen that $135(43.4 \%)$ female and $176(56.6 \%)$ male students participated in the study. While $199(64 \%)$ of these students had an athlete license, $112(36 \%)$ did not have any athlete license. While $55.6 \%$ of the students participating in the study were between the ages of $18-20$, only $3.5 \%$ were between the ages of $27-29$. Considering the distribution by year of study, $148(47.6 \%)$ students were in the first year, $129(41.5 \%)$ were in the second year and $34(10.9 \%)$ were in the third year. Considering the distribution of the participants according to their residence, 190 (61.1\%) students lived with their families, 58 (18.6\%) students lived in a house separate from their families, and $63(20.3 \%)$ students lived in the dormitory.

\section{Findings}

In this section, the findings obtained for the research questions are included.

Table 1. Distribution of students according to their demographic features

\begin{tabular}{|l|l|l|}
\hline \multicolumn{2}{|l|}{ N } & $\%$ \\
\hline Gender & 135 & 43.4 \\
\hline Famele & 176 & 56.6 \\
\hline Male & \multicolumn{2}{|l|}{} \\
\hline Licence Status & 199 & 64 \\
\hline Available & 112 & 36 \\
\hline Not available & \multicolumn{2}{|l|}{} \\
\hline Age (Year) & 173 & 55.6 \\
\hline $18-20$ & 100 & 32.2 \\
\hline 21-23 & 27 & 8.7 \\
\hline 24-26 & 11 & 3.5 \\
\hline 27-29 & \multicolumn{2}{|l|}{} \\
\hline Class Level & 148 & 47.6 \\
\hline 1.Class & 129 & 41.5 \\
\hline 2.Class & 34 & 10.9 \\
\hline 3.Class & \multicolumn{2}{|l|}{} \\
\hline Place of Residance & 190 & 61.1 \\
\hline With family & 58 & 18.6 \\
\hline At student house & 63 & 20.3 \\
\hline Student dormitory & $\mathbf{3 1 1}$ & $\mathbf{1 0 0}$ \\
\hline Total & \multicolumn{2}{|l|}{} \\
\hline
\end{tabular}




\section{Macrothink}

The results of the t-test for independent groups conducted to test whether the mean scores of the dimensions of the Quality of University Life Scale differed according to the gender variable are shown in Table 2 below.

Table 2. T-test results according to the sub-dimensions of the Quality of University Life Scale, the gender score means and standard deviation values

\begin{tabular}{|c|c|c|c|c|c|c|c|}
\hline & Gender & $N$ & $\bar{X}$ & $s s$ & $s d$ & $t$ & $p$ \\
\hline \multirow{2}{*}{ Lecturer-student communication } & Male & 176 & 3.1070 & .68318 & 309 & 1.494 & .136 \\
\hline & Female & 135 & 2.9914 & .66770 & & & \\
\hline \multirow{2}{*}{ Identity } & Male & 176 & 3.1364 & .93615 & 309 & .487 & .627 \\
\hline & Female & 135 & 3.0859 & .86336 & & & \\
\hline \multirow{2}{*}{ Social opportunities } & Male & 176 & 2.8818 & .61867 & 309 & 2.139 & $.033 *$ \\
\hline & Female & 135 & 2.7259 & .66005 & & & \\
\hline \multirow{2}{*}{ Participation in decisions } & Male & 176 & 2.8911 & .49567 & 309 & -2.964 & $.003 *$ \\
\hline & Female & 135 & 3.0543 & .46200 & & & \\
\hline \multirow{2}{*}{ Student-student communication } & Male & 176 & 2.9801 & .63721 & 309 & 4.338 & $.000 *$ \\
\hline & Female & 135 & 2.6556 & .67530 & & & \\
\hline \multirow{2}{*}{ Future } & Male & 176 & 3.1989 & .87880 & 309 & .677 & .499 \\
\hline & Female & 135 & 3.1333 & .80029 & & & \\
\hline \multirow{2}{*}{ Classroom Environment } & Male & 176 & 2.8040 & .74349 & 309 & .163 & .871 \\
\hline & Female & 135 & 2.7907 & .66299 & & & \\
\hline
\end{tabular}

Note. ${ }^{*} p<0.05$.

As seen in Table 2 above, as a result of the t-test, there were no significant differences in terms of gender in the student-instructor communication, identity, future and classroom environment dimensions of Quality of University Life Scale $(\mathrm{p}>.05)$. However, a statistically significant difference was found in favor of males in terms of social opportunities dimension, in favor of females in participation in decision dimension, and in favor of males in the student-student communication dimension $(p<.05)$.

The results of the t-test for independent groups conducted to test whether the mean scores of the dimensions of the Quality of University Life Scale differed according to whether the students participating in the study had a sports license or not are shown in Table 3 below. 


\section{Macrothink}

Table 3. T-test results according to the sub-dimensions of the Quality of University Life Scale of the athlete license score means and standard deviation values

\begin{tabular}{|l|l|l|l|l|l|l|l|}
\hline & Athlete License & $\boldsymbol{N}$ & $\boldsymbol{X}$ & $\boldsymbol{s}$ & $\boldsymbol{s} \boldsymbol{d}$ & $\boldsymbol{t}$ & $\boldsymbol{p}$ \\
\hline \multirow{3}{*}{ Lecturer-student communication } & Available & 119 & 3.0503 & .67958 & 309 & -.227 & .821 \\
\cline { 2 - 10 } & Not available & 112 & 3.0685 & .67767 & & & \\
\hline \multirow{3}{*}{ Identity } & Available & 119 & 3.0884 & .92606 & 309 & -.676 & .500 \\
\cline { 2 - 9 } & Not available & 112 & 3.1607 & .86611 & & & \\
\hline \multirow{3}{*}{ Participation in decisions } & Available & 119 & 2.7960 & .63308 & 309 & -.666 & .506 \\
\cline { 2 - 9 } & Not available & 112 & 2.8464 & .65539 & & & \\
\hline \multirow{3}{*}{ Student-student communication } & Available & 119 & 2.9162 & .51052 & 309 & -2.218 & $\mathbf{. 0 2 7 *}$ \\
\cline { 2 - 9 } & Not available & 112 & 3.0432 & .43366 & & & \\
\hline \multirow{3}{*}{ Future } & Available & 119 & 2.8744 & .67648 & 309 & 1.229 & .220 \\
\hline \multirow{3}{*}{ Classroom Environment } & Available & 119 & 3.1139 & .88976 & 309 & -1.576 & .116 \\
\cline { 2 - 9 } & Not available & 112 & 3.2708 & .75208 & & & \\
\hline & Available & 119 & 2.8015 & .72791 & 309 & .109 & .914 \\
\cline { 2 - 8 } & Not available & 112 & 2.7924 & .67608 & & & \\
\hline
\end{tabular}

Note. ${ }^{*} p<0.05$.

As seen in Table 3 above, as a result of t-test for independent groups, the Quality of University Life Scale was not found to be significant in terms of whether students had a license or not in terms of instructor-student communication, social opportunities, the student-student communication, identity, future and classroom environment dimensions $(p>.05)$. However, a statistically significant difference was found in favor of those who did not have a license in the participation in decisions dimension $(\mathrm{p}<.05)$.

The results of one-way analysis of variance (ANOVA) conducted to test whether Quality of University Life Scale dimensions differed according to year of study are shown in Table 4 below. 


\section{Macrothink}

Table 4. Anova test results according of the Quality of University Life Scale, class level variable means and standard deviation values

\begin{tabular}{|c|c|c|c|c|c|c|c|c|}
\hline & & $N$ & $\bar{X}$ & ss & $s d$ & $F$ & $p$ & Lsd \\
\hline \multirow{3}{*}{$\begin{array}{l}\text { Lecturer-student communication } \\
\text { Identity }\end{array}$} & 1.Class & 148 & 3.1160 & .66173 & 308 & 1.711 & .182 & \\
\hline & 2.Class & 129 & 3.0336 & .69171 & & & & \\
\hline & 3.Class & 34 & 2.8873 & .68007 & & & & \\
\hline \multirow{3}{*}{$\begin{array}{l}\text { Social opportunities } \\
\text { Participation in decisions }\end{array}$} & 1.Class & 148 & 3.3730 & .86304 & 308 & 12.419 & $.000 *$ & $1>2$ \\
\hline & 2.Class & 129 & 2.8713 & .89750 & & & & $1>3$ \\
\hline & 3.Class & 34 & 2.9118 & .81529 & & & & \\
\hline \multirow{3}{*}{$\begin{array}{l}\text { Student-student communication } \\
\text { Future }\end{array}$} & 1.Class & 148 & 2.8824 & .68410 & 308 & 5.061 & $.007^{*}$ & $1>3$ \\
\hline & 2.Class & 129 & 2.8186 & .55702 & & & & $2>3$ \\
\hline & 3.Class & 34 & 2.5000 & .66652 & & & & \\
\hline \multirow{3}{*}{$\begin{array}{l}\text { Classroom Environment } \\
\text { Lecturer-student communication }\end{array}$} & 1.Class & 148 & 3.0248 & .47115 & 308 & 2.432 & .090 & \\
\hline & 2.Class & 129 & 2.8979 & .47247 & & & & \\
\hline & 3.Class & 34 & 2.9314 & .58476 & & & & \\
\hline \multirow{3}{*}{$\begin{array}{l}\text { Identity } \\
\text { Social opportunities }\end{array}$} & 1.Class & 148 & 2.8750 & .72228 & 308 & 2.393 & .093 & \\
\hline & 2.Class & 129 & 2.8605 & .62493 & & & & \\
\hline & 3.Class & 34 & 2.6029 & .58749 & & & & \\
\hline \multirow{3}{*}{$\begin{array}{l}\text { Participation in decisions } \\
\text { Student-student communication }\end{array}$} & 1.Class & 148 & 3.3378 & .79586 & 308 & 7.976 & $.000^{*}$ & $1>2$ \\
\hline & 2.Class & 129 & 3.0879 & .84832 & & & & $1>3$ \\
\hline & 3.Class & 34 & 2.7549 & .87351 & & & & $2>3$ \\
\hline \multirow{3}{*}{ Future } & 1.Class & 148 & 2.7990 & .69109 & 308 & .015 & .985 & \\
\hline & 2.Class & 129 & 2.7926 & .73959 & & & & \\
\hline & 3.Class & 34 & 2.8162 & .68343 & & & & \\
\hline
\end{tabular}

Note. ${ }^{*} p<0.05$.

As seen in Table 4 above, as a result of the one-way analysis of variance (ANOVA), there was no significant difference according to year of study in the instructor-student communication, participation in decisions, the student-student communication and classroom environment dimensions of the Quality of University Life Scale $(\mathrm{p}>.05)$. However, a statistically significant difference was found in identity, social opportunities and future dimensions $(\mathrm{p}<.05)$ LSD test, one of the post hoc tests, was performed to determine in which groups these differences existed. LSD test is suitable for use in cases where variances are equal and samples are not equal (Kayri, 2009, p. 56). As a result of LSD test, it is seen that the mean scores of the 1st year students in identity dimension $(\bar{X}=3.3730)$ were significantly higher than the mean scores of the 2 nd year students $(\bar{X}=2.8713)$, and 3rd year students $(\bar{X}=2.9118)$. The mean scores of the 1 st year students in terms of social opportunities dimension $(\bar{X}=2.8824)$ were 


\section{Macrothink

significantly higher than the mean scores of the 3rd year students $(\bar{X}=2.50)$; and the mean scores of the 2 nd year students $(\bar{X}=2.8166)$ were significantly higher than the mean scores of the 3rd year students $(\bar{X}=2.50)$. In the future dimension, the mean scores of the 1 st year students $(\bar{X}=3.3378)$ were significantly higher than the mean scores of the 2nd year students $(\bar{X}=3.0879)$ and the 3 rd year students $(\bar{X}=2.7549)$; and the mean scores of the 2 nd year students $(\bar{X}=3.0879)$ were significantly higher than the mean scores of the 3rd year students $(\bar{X}=2.7549)$.

The results of one-way analysis of variance (ANOVA) conducted to test whether Quality of University Life Scale dimensions differed according to age distribution are shown in Table 5 below. 


\section{Macrothink}

Journal of Educational Issues

ISSN 2377-2263

2020, Vol. 6, No. 2

Table 5. Anova test results by age distribution of the Quality of Life Scale variable means and standard deviation values

\begin{tabular}{|c|c|c|c|c|c|c|c|c|}
\hline & Age(Ye) & $N$ & $\bar{X}$ & $s s$ & $s d$ & $\boldsymbol{F}$ & $p$ & Lsd \\
\hline \multirow{4}{*}{$\begin{array}{l}\text { Lecturer-student communication } \\
\text { Identity }\end{array}$} & $18-20(1)$ & 173 & 3.0231 & .66213 & 307 & 5.020 & $.002 *$ & $3>1$ \\
\hline & $21-23(2)$ & 100 & 2.9700 & .66935 & & & & $3>2$ \\
\hline & $24-26(3)$ & 27 & 3.4815 & .64605 & & & & \\
\hline & $27-29(4)$ & 11 & 3.3333 & .71880 & & & & \\
\hline \multirow{4}{*}{$\begin{array}{l}\text { Social opportunities } \\
\text { Participation in decisions }\end{array}$} & $18-20(1)$ & 173 & 3.1480 & .87062 & 307 & .525 & .665 & \\
\hline & $21-23(2)$ & 100 & 3.0320 & .94312 & & & & \\
\hline & $24-26(3)$ & 27 & 3.1259 & 1.00483 & & & & \\
\hline & $27-29(4)$ & 11 & 3.3091 & .86424 & & & & \\
\hline \multirow{4}{*}{$\begin{array}{l}\text { Student-student communication } \\
\text { Future }\end{array}$} & $18-20(1)$ & 173 & 2.7931 & .66364 & 307 & .452 & .716 & \\
\hline & $21-23(2)$ & 100 & 2.8400 & .65874 & & & & \\
\hline & $24-26(3)$ & 27 & 2.7778 & .40510 & & & & \\
\hline & $27-29(4)$ & 11 & 3.0000 & .60663 & & & & \\
\hline \multirow{4}{*}{$\begin{array}{l}\text { Classroom Environment } \\
\text { Lecturer-student communication }\end{array}$} & $18-20(1)$ & 173 & 2.9923 & .44490 & 307 & 1.519 & .210 & \\
\hline & $21-23(2)$ & 100 & 2.9583 & .52565 & & & & \\
\hline & $24-26(3)$ & 27 & 2.7778 & .40298 & & & & \\
\hline & $27-29(4)$ & 11 & 2.9697 & .83273 & & & & \\
\hline \multirow{4}{*}{$\begin{array}{l}\text { Identity } \\
\text { Social opportunities }\end{array}$} & $18-20(1)$ & 173 & 2.8613 & .70524 & 307 & .646 & .586 & \\
\hline & $21-23(2)$ & 100 & 2.7750 & .63315 & & & & \\
\hline & $24-26(3)$ & 27 & 2.8611 & .56896 & & & & \\
\hline & $27-29(4)$ & 11 & 3.0227 & .75378 & & & & \\
\hline \multirow{4}{*}{$\begin{array}{l}\text { Participation in decisions } \\
\text { Student-student communication }\end{array}$} & $18-20(1)$ & 173 & 3.1869 & .87035 & 307 & .527 & .664 & \\
\hline & $21-23(2)$ & 100 & 3.0967 & .84260 & & & & \\
\hline & $24-26(3)$ & 27 & 3.2963 & .73574 & & & & \\
\hline & $27-29(4)$ & 11 & 3.2727 & .74264 & & & & \\
\hline \multirow{4}{*}{ Future } & $18-20(1)$ & 173 & 2.7775 & .72209 & 307 & .437 & .727 & \\
\hline & $21-23(2)$ & 100 & 2.7875 & .70297 & & & & \\
\hline & 24-26(3) & 27 & 2.9167 & .67582 & & & & \\
\hline & $27-29(4)$ & 11 & 2.9318 & .67167 & & & & \\
\hline
\end{tabular}

Note. ${ }^{*} p<0.05$.

As seen in Table 5 above, as a result of the one-way analysis of variance conducted, it was observed that the mean scores of identity, social opportunities, participation in decisions, the student-student communication, future and class environment dimensions of the university 
life quality scale did not differ significantly according to age distribution $(p>.05)$, while only instructor-student communication dimension appears to have differed significantly according to age distribution $(p>.05)$. LSD test, which is one of the post hoc tests, was carried out to determine the age groups in which the instructor-student communication dimension differed. As a result of this test, the mean scores of the instructor-student communication dimension of the students in the 24-26 age group $(\bar{X}=3.4815)$ were found to be significantly higher than the mean scores of the students in the $21-23$ age group $(\bar{X}=2.97)$ and $18-20$ age group $(\bar{X}=$ 3.0231).

The results of one-way analysis of variance (ANOVA) conducted to test whether Quality of University Life Scale scores differed according to students' residence are shown in Table 6 below.

Table 6. ANOVA test results by residence distribution of the Quality of Life Scale variable means and standard deviation values

\begin{tabular}{|c|c|c|c|c|c|c|c|c|}
\hline & Residence & $N$ & $\bar{X}$ & ss & $s d$ & $F$ & $p$ & Lsd \\
\hline \multirow{3}{*}{$\begin{array}{l}\text { Lecturer-student communication } \\
\text { Identity }\end{array}$} & With family & 190 & 3.0930 & .69101 & 308 & 2.080 & .127 & \\
\hline & Student House & 58 & 3.1063 & .59946 & & & & \\
\hline & Student dormitory & 63 & 2.9021 & .69344 & & & & \\
\hline \multirow{3}{*}{$\begin{array}{l}\text { Social opportunities } \\
\text { Participation in decisions }\end{array}$} & With family & 190 & 3.2011 & .90091 & 308 & 2.450 & .088 & \\
\hline & Student House & 58 & 3.0310 & .94761 & & & & \\
\hline & Student dormitory & 63 & 2.9302 & .85093 & & & & \\
\hline \multirow{3}{*}{$\begin{array}{l}\text { Student-student communication } \\
\text { Future }\end{array}$} & Student House & 190 & 2.7874 & .67224 & 308 & .443 & .643 & \\
\hline & Student dormitory & 58 & 2.8448 & .59003 & & & & \\
\hline & With family & 63 & 2.8667 & .59024 & & & & \\
\hline \multirow{3}{*}{$\begin{array}{l}\text { Classroom Environment } \\
\text { Lecturer-student communication }\end{array}$} & Student dormitory & 190 & 2.9237 & .49232 & 308 & 1.860 & .157 & \\
\hline & With family & 58 & 3.0603 & .50984 & & & & \\
\hline & Student House & 63 & 2.9868 & .44228 & & & & \\
\hline \multirow{3}{*}{$\begin{array}{l}\text { Identity } \\
\text { Social opportunities }\end{array}$} & With family & 190 & 2.8724 & .68320 & 308 & .597 & .551 & \\
\hline & Student House & 58 & 2.7802 & .64393 & & & & \\
\hline & Student dormitory & 63 & 2.7937 & .66983 & & & & \\
\hline \multirow{3}{*}{$\begin{array}{l}\text { Participation in decisions } \\
\text { Student-student communication }\end{array}$} & With family & 190 & 3.1456 & .90096 & 308 & .438 & .646 & \\
\hline & Student House & 58 & 3.1552 & .74199 & & & & \\
\hline & Student dormitory & 63 & 3.2593 & .76069 & & & & \\
\hline \multirow{3}{*}{ Future } & With family & 190 & 2.8316 & .71218 & 308 & .835 & .435 & \\
\hline & Student House & 58 & 2.7974 & .71245 & & & & \\
\hline & Student dormitory & 63 & 2.6984 & .69584 & & & & \\
\hline
\end{tabular}

Note. ${ }^{*} p<0.05$ 
As seen in Table 6 above, as a result of the one-way analysis of variance, it is seen that the mean scores regarding the dimensions of the Quality of University Life Scale did not differ significantly according to the student's place of residence $(p>.05)$. In short, the students' residence with their families, their residence at a student house or in the dormitory does not cause any difference in the scores of the students on the Quality of University Life Scale.

\section{Discussion}

The aim of this study is to determine the school life quality perceptions of university students receiving sports education. The findings obtained in this direction and other studies were examined. In the examinations made, different findings were determined according to the characteristics of the variables in other studies. It is not possible to reach a single conclusion in terms of the dimensions of the university life quality and the variables of the participants, but when other studies are examined, for example; In his study, Özdemir explained that the quality of university life expresses to what extent university life meets the needs and expectations of students, satisfaction and pleasure in university life, that is, how the student perceives the internal and external conditions in his/her life. He also determined that students with high social skill scores had a high quality of life perception (Özdemir, 2018).

However, a statistically significant difference was found in favor of males in terms of social opportunities dimension, in favor of females in participation in decisions dimension, and in favor of males in the student-student communication dimension (Doğanay \& Sar1, 2006) determined in their study that the dimension with the highest mean score was "Identity" and the dimension with the lowest mean score was "Classroom environment".

In the study, no difference was found among students regarding the gender variable and quality of life. Studies with similar results are observed. It can be said that there was no significant difference between the gender variable and the participants 'quality of life, and it was not an effective variable on students' perceptions of quality of school life according to gender (Demirdă̆, 2019; Aykit, 2017; Y1lmaz, 2019).

However, when the dimensions were examined, it was found that there was a difference in some studies in terms of gender and year of study. Students' level of quality of university life varied significantly according to gender, faculty and membership to the student community. It was observed that there was no significant difference in terms of year of study, monthly income and type of residence where families reside (Eriş \& Anıl, 2015). Other study gender is significantly influence the social relationships and environment well-being among university students. However, this study gender was not significantly influence the psychological well-being among university students (Al-Naggar et al., 2013).

There was no significant difference in terms of year of study in the instructor-student communication, participation in decisions, the student-student communication and classroom environment dimensions of the Quality of University Life Scale. However, a statistically significant difference was found in identity, social opportunities and future dimensions: In fact, in some studies, it was found that the dimension that students perceived the quality at the highest level according to their perceptions about university life quality was "Participation in 
decisions", and the dimension they perceived at the lowest level was "Future" (Argon \& Kösterelioğlu, 2009). In this study, it is seen that students from the age group of 24-26 differed from the younger students significantly in the instructor-student communication dimension according to the age distribution.

It was determined that the findings obtained differed from other studies. When the relationship between Yalova University students' ages and quality of university life was examined, it was found that $\mathrm{p}$-value was 0 and there was a significant difference in favor of students aged 19 and under compared to those aged 21 and over (Yüksel Oktay et al., 2019). According to the findings obtained, the mean scores of the 1st year students in Identity dimension were significantly higher than the mean scores of the 2 nd year and $3^{\text {rd }}$ year students some studies are similar to this study in this respect. Students stated that as the year of study increased, their perception of quality of their school life decreased (Cenksever \& Sar1, 2012); (Şahin \& Özbay, 1999). Researchers explained that these results were related to maturation and experience. When the studies were examined, it was seen that there are studies in which different findings were obtained in students' perceptions of the quality of life according to the status of doing sports. When the mean scores that the students obtained from the Quality of Life Scale were examined, it was observed that the students who stated that they did not do sports had a higher quality of life than the students who stated that they were doing sports. Although they did not do sports actively, the fact that they had sports backgrounds was thought to be effective in students' quality of life (Ulukan \& Esenkaya, 2020).

According to the results of simple linear regression analysis conducted to demonstrate the power of university students' sporting attitudes to explain their quality of life, it was found that the sporting attitude had a positive and significant relationship at the level of quality of life (Çoban et al., 2020).

In the research conducted by Sönmezoğlu et al. (2020), the quality of life of those who did sports in terms of instructor-student communication, social opportunity, the student-student communication and future sub-dimensions was found to be higher. However, in this study, as a result of the t-test regarding the variable of the athlete license, there was not a significant difference in terms of whether the students held a license or not in the instructor-student communication, social opportunities, the student-student communication, identity, future and classroom environment dimensions of the Quality of University Life Scale. However, a statistically significant difference was found in favor of those who did not have a license in the participation in decisions dimension.

The reason for the significant difference in favor of those who did not have a license in participation in the decisions dimension may be due to the high expectations of students with a sports license from the university. The students' residence with their families, their residence at a student house or in the dormitory did not cause any difference in the scores of the students on the Quality of University Life Scale.

According to the findings we obtained from our research and other studies, it is not possible to explain the quality of university life in a single dimension. At the same time, when examined in terms of variables, different researchers found different findings for each 
variable.

The following can be concluded from these:

$\checkmark \quad$ There may be a difference in the perceptions of quality of university life of students from different socio-cultural levels in different universities.

$\checkmark$ Students' perceptions of quality of life in different faculties of universities may be different.

$\checkmark$ Depending on the number of lecturers and students in universities, limited life opportunities may affect this situation.

It is thought that increasing the quality of life in universities will increase the academic success of the student group, and faculties will become institutions that train more qualified, happier and equipped teachers.

\section{Suggestions}

Social-cultural activities organized at the school, activities such as activities related to the administrative staff working in the school and the unit, organized activities such as socio-cultural activities organized at the school to read again, high university life quality thinking and evaluation can be beneficial in relation to academic achievements and psychological and sociological factors. In addition, it is thought that it is important to achieve high academic success with the attendees and to update the graduate quality perceptions. When the educational extracurricular activities are examined, time to increase such activities or to bring better levels, or to meet expectations, positive perceptions towards the school and others that pay off. In this sense, it should be learned what they expect from the faculties they are affiliated with. This discovery will help research to improve the quality of life perceptions of research.

\section{Resources}

Al-Huwailah, A. (2017). Quality of Life and Emotional Intelligence in a Sample of Kuwait University Students. Journal of Education and Practice, 8(3), 180-185.

Al-Naggar, R. A., Osman, M. T., \& Musa, R. (2013). Quality of Life among University Students in a Single Malaysian Institute (Vol. 75, No. 10, pp. 165-179).

Argon, T., \& KöstereliOğlu, M. (2009). Üniversite Öğrencilerinin Üniversite Yaşam Kalitesi Ve Fakülte Kültürüne İlişkin Algilari. Elektronik Sosyal Bilimler Dergisi, \&(30), 43-61.

Aykıt, S., \& Baba Öztürk, M. (2017). Öğrenci Algılarına Göre Liselerde Yaşam Kalitesi. Journal of International Social Research, 10(51). https://doi.org/10.17719/jisr.2017.1799

Cenksever-Önder, F., \& Sarı, M. (2012). İlköğretim öğrencilerinde zorbalık ve okul yaşam kalitesi. Elementary Education Online, 11(4), 897-914.

Çilhoroz, Y., \& Işık, O. (2018). Physıcal Qualıty Assessment in Healthcare Organızatıons. Journal of International Health Sciences and Management, 4(7), 9-20. Retrieved from 
https://dergipark.org.tr/tr/pub/jihsam/issue/40106/388027

Çoban, Ü., Bayazıt, B., \& Uca, M. (2020). Üniversite Öğrencilerinin Spora Yönelik Tutumlarinin Yaşam Kalitesi, Düzeylerine Etkisinin İncelenmesi: Doğu Marmara Bölgesi Üniversiteleri Örneği. OPUS Uluslararası Toplum Araştırmaları Dergisi, 15(26), 4362-4385. https://doi.org/10.26466/opus.665339

Demırdag, S., \& Sarıcı, H. (2019). Üniversite Öğrencilerinin Yaşam Kalitelerinin İncelenmesi: Ereğli Eğitim Fakültesi Örneği. Karaelmas Eğitim Bilimleri Dergisi, 7(1), 57-73

Doğanay, A., \& Sarı, M. (2006). Öğrencilerin Üniversitedeki Yaşam Kalitesine İlişkin Algılarının Demokratik Yaşam Kültürü Çerçevesinde Değerlendirilmesi (Çukurova Üniversitesi Örneği). Türk Eğitim Bilimleri Dergisi, 4(2), 107-128.

Eriş, H. M., \& Anıl, D. (2015). Üniversite Öğrencilerinin Yaşam Kalitesi Düzeylerinin Bazı Değişkenlere Göre İncelenmesi. Hacettepe Üniversitesi Ĕgitim Fakültesi Dergisi. https://doi.org/10.16986/HUJE.2015014183

Ersoy, A. F. (2005). Huzurevlerinde yasayan yasliların yasam kalitesi, III. In Ş. Ergin (Ed.), Ulusal Yaşlılık Kongresi (pp. 379-390). İzmir: YASAD Yayınları.

Gönen, E., \& Özmete, E. (2003). Quality of life and life satisfaction perspective of elderly women and men in Turkey. Yaşlı Sorunları Araştırma Dergisi, 3(1), 22-36.

Karaduman, A. (2006). Physical independence and quality of life in old age. In J. Troisi \& Y. G. Kutsal (Eds.), Aging in Turkey (pp. 65-84). Ankara: Hacettepe Üniversitesi GEBAM Yayınları.

Kayri, M. (2009). Araştirmalarda gruplar arasi farkin belirlenmesine yönelik çoklu karşılaştirma (post-hoc) teknikleri. Journal of Social Science, 55.

Mok, M., \& Flyyn, M. (2002). Determinants of students' quality of school life: A path model. Learning Environments Research, 5(3), 275-300. https://doi.org/10.1023/A:1021924322950

Özdemir, N. (2018). The Relationship Between Hidden Curriculum Perception and University Life Quality in Sports Education. Universal Journal of Educational Research, 6(4), 742-750. https://doi.org/10.13189/ujer.2018.060417

Şahin, M., \& Özbay, Y. (1999). Üniversite öğrencilerinin empatik sınıf atmosferine ilişkin algılamalarının farklı değişkenler açısından incelenmesi. Hacettepe Üniversitesi Ĕ̆itim Fakültesi Dergisi, 15, 74-83.

Sönmezoğlu, U., Gökçe, H., \& Karakaş, G. (2020). Pamukkale Üniversitesi Öğrencilerinin Yaşam Kalitesi, Örgütsel İmaj ve Özdeşleşme Düzeyleri Arasındaki İlişkilerin İncelenmesi. MANAS Sosyal Araştırmalar Dergisi, 9(3), 1803-1819. https://doi.org/10.33206/mjss.548872

Trajkovska-Anchevska, Z., \& Trajkov, İ. (2019). Quality of Life at Patients with Malignancies. The Eurasia Proceedings of Educational and Social Sciences, 15, 65-69.

Ulukan, H., \& Esenkaya, A. (2020). Aydın Adnan Menderes Üniversitesi Spor Bilimleri 


\section{Macrothink}

Fakültesi Öğrencilerinin Yaşam Kalitesi ile Mutluluk Düzeylerinin İncelenmesi. Akdeniz Spor Bilimleri Dergisi, 3(1), 185-201. https://doi.org/10.38021/asbid.746146

Y1lmaz, G., \& Karaca, S. (2019). Spor Yapan Ve Sedanter Üniversite Öğrencilerinin Beslenme Bilgi Tutum Ve Yaşam Kalitelerinin İncelenmesi. Beden Eğitimi Ve Spor Bilimleri Dergisi, 13(3), 258-266. Retrieved from https://dergipark.org.tr/tr/pub/bsd/issue/50922/ 664645

Yüksel Oktay, E., Karahan, K., Yıldırım, Y., \& Doğan, A. (2019). Yalova Üniversitesi Öğrencilerinin Üniversite Yaşam Kalitesi Algılarının Değerlendirilmesi. Yalova Sosyal Bilimler Dergisi, 9(19), 17-43.

\section{Copyright Disclaimer}

Copyright for this article is retained by the author(s), with first publication rights granted to the journal.

This is an open-access article distributed under the terms and conditions of the Creative Commons Attribution license (http://creativecommons.org/licenses/by/3.0/). 